\title{
STRATEGI MEDIA RELATIONS HUMAS DALAM MENINGKATKAN KUALITAS PELAYANAN KELUARGA BERENCANA (KB) PADA BADAN KEPENDUDUKAN DAN KELUARGA BERENCANA NASIONAL (BKKBN) PROVINSI NTT
}

\author{
Jim Briand Kolianan, Aloysius Liliweri, Lenny Tamunu. \\ Public A dministration, Faculty of A dministrative Scieance-U niversity of B rawijaya
}

\begin{abstract}
A dapun tujuan dari penelitian ini adalah untuk mengetahui Strategi Media Relations Humas Badan Kependudukan dan Keluarga Berencana Nasional (BKKBN) Provinsi NTT dalam Meningkatkan Kualitas Pelayanan Keluarga Berencana (KB). Metode yang digunakan dalam penelitian ini adalah jenis penelitian kualitatif ini membahas secara mendalam untuk lebih mengetahui fenomena-fenomena seperti opini, keinginan, perasaan, dan perilaku relasi media tentang strategi dan kegiatan media relation yang dijalankan oleh BKKBN. Ruang lingkup dalam penelitian adalah pada B agian Humas K antor Badan Kependudukan dan Keluarga Berencana Nasional (BKKBN) Provinsi NTT yang memberikan layanan kepada masyarakat. Teknik pengumpulan data yang digunakan dalam penelitian ini adalahW awancara, observasi dan studi documenter. Sedangkan Teknika analisis data yang digunakan adalah Analisis data menggunakan teknik analisis deskriptif kualitatif. Hasil Penelitian yang dilakukan yaitu Kualitas pelayanan melalui strategi media relations di Humas BKKBN Provinsi NTT di atas dapat disimpulkan bahwa pelayanan melalui strategi media relations di Humas BKKBN Provinsi NTT sudah berjalan dengan baik karena: a) adanya ketepatan waktu dalam memberikan informasi; b) memberikan informasi atau berita kepada media massa di dalam menangani permasalahan atau isu-isu yang timbul di masyarakat serta kemauan untuk membantu pelanggan dan memberikan jasa dengan cepat; c) menimbulkan kepercayaan dan keyakinan, yang merupakan kemampuan Humas dalam menciptakan rasa rasa percaya masyarakat kepada BKK BN NTT antara lain komunikasi, kredibilitas, keamanan, kompetensi dan sopan santun; d) memberikan informasi lewat media atau publikasi dan melakukan event-event kepada masyarakat yang berkaitan dengan pengetahuan, kebutuhan masyarakat secara spesifik; dan e) menampilkan fasilitas fisik, peralatan atau teknologi dan penampilan pegawai pada Kantor Badan Koordinasi dan Keluarga Berencana (BKK BN) NTT.
\end{abstract}

Kata Kunci: Kualitas Pelayanan, Strategi Humas, Media Relations

\section{PENDAHULUAN}

Dalam era globalisasi saat ini, mulai banyak organisasi baik yang bersifat profit, non-profit yang diselenggarakan oleh negara atau pemerintah maupun organisasi di luar pemerintah menggunakan jasa Hubungan Masyarakat (Humas).K eberadaan Humas ditujukan untuk meningkatkan kualitas Iayanan yang baik di mata masyarakat. $\mathrm{H}$ al tersebut telah membuat banyak perusahaan, organisasi atau lembaga-lembaga lainnya sadar akan fungsi Humas bagi perusahaan. Humas merupakan suatu profesi yang menghubungkan antara lembaga atau organisasi kepada publiknya dan ikut menentukan kelangsungan hidup lembaga 
tersebut.Dalam Humas terdapat dua macam publik yang menjadi sasaran yakni publik internal dan publik eksternal.

Badan Kependudukan K eluarga Berencana Nasional (BKK BN) merupakan suatu lembaga pemerintah non departemen yang berkedudukan langsung dibawah presiden yang menangani bidang keluarga berencana, kependudukan, meningkatkan perlindungan dan pemenuhan hak-hak keluarga serta penanggulangan masalah kesehatan reproduksi, dan lain sebagainya.Pada dasarnya Humas merupakan proses komunikasi kepada publik untuk menjalin relasi yang baik sehingga tercapai tujuan untuk membangun, membina, dan menjaga citra yang positif di mata publik. Dalam konteks lembaga-lembaga publik seperti pemerintah, sejatinya peran melayani dan mengembangkan dukungan publik guna mencapai tujuan organisasi adalah hal yang sangat penting.Pada konteks ini, praktisi Humas harus bisa membentuk nilai-nilai, pemahaman, sikap-sikap, sampai perilaku dari publik agar sejalan dengan kebutuhan organisasi.Pesan-pesan ini dapat dikomunikasikan melalui media massa atau media lain yang dipilih sesuai dengan target sasaran, menurut Trujillo dan Toth (1987), kajian public relation atau Humas dapat dibagi menjadi tiga kelompok, yaitu: 1) Public Relations Fungsionalis (Objektif), 2) Public Relations Interpretif (Subjektif), dan 3) Public Relations K ritis.

Organisasi dianggap sebagai arena pertarungan ideologi dan ekonomi, seperti kuasa (power), pengaruh, dan kontrol. Publik yaitu koalisi dan konstituen yang mempunyai kebutuhan, nilai, dan persepsi yang berbeda-beda.Pendekatan ini kemudian fokus pada aspek-aspek politis dari organisasi, dan mengkaji bagaimana organisasi menggunakan komunikasi tawar menawar serta bernegosiasi dengan beragam koalisi dan konstituen itu. Para ilmuwan kritis juga berusaha mengekspos aspek-aspek represif, yang akibat power dan dominasi dalam organisasi sehingga dapat menawarkan pilihan alternatif untuk perubahan radikal dalam organisasi.

Untuk dapat mewujudkan prinsipprinsip diatas, Humas harus melakukan berbagai macam kegiatan komunikasi kepada publiknya dengan menggunakan media Humas sebagai sarana penyampaian informasi. M edia yang digunakan tentunya berbeda-beda sesuai dengan kelompok khalayaknya.Praktisi humas melakukan komunikasi tatap muka maupun melalui media internal seperti bulletin perusahaan. Kegiatan eksternal, Humas menggunakan media massa sebagai sarana untuk mengkomunikasikan segala informasi mengenai perusahaan. Dalam konteks ini, sasaran publik eksternal menjadi target utama dari BKK BN.Lembaga pemerintah yang menangani bidang Kependudukan dan Keluarga Berencana, tentunya BKKBN selalu berhubungan langsung dengan masyarakat serta para media massa dalam memberikan informasi kebijakankebijakan, langkah-langkah serta tindakan pemerintah untuk menangani kepentingankepentingan masyarakat.

Media massa, dalam hal ini termasuk radio, koran, dan televisi di nilai memiliki kekuatan untuk mempengaruhi opini khlayak. Dalam konteks corporate pun, media massa memegang peranan sebagai sumber informasi dan pembentukkan opini publik dan dapat menimbulkan citra suatu organisasi. M edia massa memiliki potensi untuk membangkitkan kesadaran, mengubah sikap, pendapat dan perilaku, mendorong tindakan, dan ada juga yang menyebutkan bahwa media massa bisa membantu kita merumuskan cara memandang dunia. Dengan kekuatan dan kemampuan yang dimiliki oleh media, maka peran media tidak dapat diabaikan begitu saja dalam program dan kegiatan Humas. Dalam banyak perencanaan atau kegiatan program Humas, media merupakan salah satu aspek yang diperhitungkan dan dipertimbangkan oleh perencana. 


\section{KAJIAN TEORI}

\section{Hubungan Masyarakat (HUMAS)}

Humas adalah padanan kata dari PR (Public Relation), yang banyak digunakan institusi-institusi pemerintah di Indonesia. Secara etimologis istilah public yang diterjemahkan menjadi masyarakat, kurang tepat karena padan katanya, yaitu public atau khalayak. Sedangkan masyarakat yang diterjemahkan ke dalam bahasa inggris menjadi society atau general public, pengertiannya lebih luas dari public itu sendiri. Sementara, dalam setiap kegiatan PR yang menjadi target publiknya bukan society atau general public, melainkan public, dimana public adalah bagian dari society atau general public. Padanan kata B ahasa Indonesia dari Bahasa Inggris adalah hubungan publik atau hubungan khalayak, disingkat hubpub atau hubyak.A kan tetapi istilah hubpub dan hubyak tidak familiar dan popular.A khirnya, istilah humas digunakan karena sudah demikian familiar

Dalam buku effective Public Relations (Cutlip, 2006 dalam Publisitas Universitas Kristen Petra) Public Relation adalah fungsi manajemen yang membangun dan mempertahankan hubungan yang baik dan bermanfaat antara organisasi dengan publik yang memengaruhi kesuksesan dan kegagalan organisasi tersebut. Menurut Denny Griswold (Wilcox, dkk. 2006 dalam Ardianto 2011: 9) humas adalah fungsi manajemen yang mengevaluasi publik, memperkenalkan berbagai kebijakan dan prosedur dari suatu individu atau organisasi berdasarkan kepentingan publik, dan membuat perencanaan, serta melaksanakan suatu program kerja dalam upaya memperoleh pengertian dan pengakuan publik.Public Relation adalah usaha yang terencana dan berkesinambungan untuk membangun dann mempertahankan hubungan baik serta saling pengertianantara sebuah organisasi dan publiknya (G regory 2010:2)
Dari beberapa definisi-definisi di atas penulis menarik kesimpulan mengenai Humas yaitu fungsi manajemen yang terencana dan berkelanjutan melalui organisasi yang memperkenalkan betbagai kebijakan dan prosedur dari suatu organisasi, serta melaksanakan suatu program kerja dalam upaya memperoleh pengertian dan pengakuan publik untuk mempertahankan hubungan yang baik antara organisasi dan publik.

\section{Strategi Humas}

PR adalah:

Menurut Ruslan (2006), strategi

a. Publication (Publikasi)

Setiap fungsi dan tugas Humas adalah menyelenggarakan publikasi atau menyebarluaskan informasi melalui berbagai media tentang aktivitas atau kegiatan perusahaan atau organisasi yang pantas untuk diketahui oleh publiknya.Setelah itu, menghasilkann publisitas untuk memperoleh tanggapan positif secara luas dari masyarakat.

b. Event (Penyusunan Program A cara) Merancang acara tertentu atau lebih dikenal dengan peristiwa (special event) yang dipilih dalam jangka waktu, tempat, dan objek tertentu yang khusus sifatnya untuk mempengaruhi opini public.

c. News (menciptakan berita)

Berupaya menciptakan berita melalui pres release, newslater dan bulletin dan lain-lain yang biasanya mengacu teknis penulisan $5 \mathrm{~W}+1 \mathrm{H}$ dengan sistematika penulisan "piramida terbalik", yang paling penting menjadi lead atau intro dan dan kurang penting ddiletakkan di tengah batang berita. Untuk itulah secara humas, mau tidak mau harus mempunyai kemampuan untuk menulis, karena sebagian besar tugasnya untuk tulis-menulis, khususnya dalam menciptakan publisitas.

d. Community Involvement (kepedulian kepada komunitas) 
K eterlibatan tugas sehari-hari seorang Humas adalah mengadakan kontk social dengan kelompok masyarakat tertentu untuk menjaga hubungan baik dengan pihak organisasi atau lembaga yang yang diwakilinya.

e. Inform or Image (membritahukan dan meraih citra)

Ada dua fungsi utama dari Humas, yaitu memberitahukan sesuatu kepada public atau menarik perhatian, sehingga diharapkan akan memperoleh tanggapan berupa citra positif dari suatu proses "nothing" diupayakan menjadi "something". Dari yang tidak tahu menjadi tahu, setelah tahu menjadi suka, dan kemudian diharapkan timbul seusatu (something) yang berupa citra.

f. Lobby or Negotiation (pendekatan dan bernegosiasi)

Ketrampilan untuk melobi secara pendekatan pribadi dan kemampuan bernegosiasi sangat diperlukan bagi seorang Humas.Tujuan lobi adalah untuk mencapai kesepakataan (deal) atau memperoleh dukungan dari individu dan lembaga yang berpengaruh terhadap kelangsungan bisnis perusahaan.

g. Social Responsibility (tanggung jawab social)

Memiliki tanggung jawab social dalam aktivitas Humas menunjukkan bahwa perusahaan memiliki kepedulian terhadap masyarakat. $\mathrm{Hal}$ ini akan meningkatkan citra perusahaan di mata public.Saat ini banyak perusahaan menjadikan kegiatan social sebagai aktivitas yang harus dilakukan.Bentuknya beragam seperti peduli banjir, memberikan beasiswa, santunan anak yatim, pengobatan gratis, dan masi h banyak kegiatan lainnya.

\section{Media Relation}

Mengutip definisi Public Relations Society of America (PRSA), Baran $(2004,361)$ mendefinisikan Media Relations sebagai “...the public relations professional maintain good relations with professionals in the media, undestrand their deadlines and other restraints, and earn their trust".

Lesly (1991:7) memberikan definisi Media Relations sebagai hubungan dengan mediakomunikasi untuk melakukan publisitas atau merespon kepentingan media terhadap kepentingan organisasi.

Iriantara (2005:32) mengartikan Media Relations merupakan bagian dari Public Relations eksternal yang membina dan mengembangkan hubungan baik dengan media massa sebagai sarana komunikasi antara organisasi dengan publik untuk mencapai tujuan organisasi.

M enurut Ruslan (2006 : 187-194), kegiatan yang berkaitan dengan Media Relation adalah:

1. Press Conference

Press Conference adalah suatu pertemuan (kontak) khusus dengan pihak pers yang bersifat resmi atau sengaja disilenggarakan oleh Humas, yang bertindak sebagai narasumber dalam upaya menjelaskan suatu rencana atau permasalahan tertentu yang tengah dihadapinya dalam bentuk acara press conference yang telah ditetapkannya waktu, tempat, tema press conference dengan sekelompok wartawan yang masing-masing mewakili berbagai media massa yang di daftar sebagai peserta yang di undang secara resmi.

2. Press Tour

Sejumlah wartawan yang berasal dari berbagai media massa yang telah di kenal baik oleh Humas bersangkutan diajak wisata kunjungan ke suatu event khusus, atau peninjauan ke luar kota bersamaan dengan pejabat instansi atau pemimpin perusahaan sebagai pengundang (tuan rumah) selama lebih dari satu hari, untuk meliput secara langsung mengenai kegiatan tertentu.

3. Preess Reception

Pertemuan pers semacam ini, yaitu jamuan pers/wartawan yang bersifat social, menghadiriacara resepsi atau 
seremonial tertentu baik formal maupun informal.Ada juga melalui acara olahraga bersama, kumpul bersama dalam acara ulang tahun perusahaan dan pada acara keagamaan seperti berbuka puasa bersama dann merayakan hari natal.

4. Press Briefing

Press briefing termasuk bentuk jumpa pers secara resmi yang diselenggarakan secara periodic tertentu, biasanya pada awal/akhir bulan oleh pihak humas atau pimpinan dan pejabat tinggi instansi bersangkutan.

5. Press Statement

Biasanya keterangan pers di sini bias dilakukan kapan dan dimana saja oleh narasumber, tanpa adanya undangan resmi. M ungkin pemberitaannya cukup dilakukan melalui telepon kepada wartawan yang bersangkutan.

6. Press Interview

Biasanya inisistif wawancara dating dari pihak setelah melalui perjanjian atau konfirmasi dengan narasumbernya.Hal ini dilakukan untukmeminta keterangan, komentar, pendapat dan sebagiannya tentang suatu masalah yang tengah actual dan factual dalam masyarakat.

7. Press Gathering

$Y$ aitu pertemuan pers secara informal, khususnya hubungan (good relationship) antara pihak Humas dan wartawan media massa dalam suatu acara social keagamaan atau aktivitas olahraga.

Dari bentuk-bentuk kegiatan

Media Relations Media Relations yang dikemukakan oleh Ruslan dan Soemirat, terdapat beberapa kegiatan Media Relationyang sama. Maka, penulis menyimpulkan untuk penelitian ini penulis menggunakan kegiatan-kegiatan Media Relations seperti press conference, press tour, press receptions, press briefing, press statement, press interview, press gathering, press release, dan wawancara.

\section{Media Massa}

M enurut A rdianto (2010:43) media massa adalah saluran yang ddigunakan dalam menyampaikan informasi kepada khalayak banyak. Dengan media massa orang dapat menyebarluaskan sesuatu. Ini merupakan kekuatan tersendiri yang dibutuhkan oleh bermacam-macam kepentingan. Melalui media massa orang melakukan pengendalian atau control terhadap suatu perkembangan. Ciri khas dari media massa adalah memiliki kemampuan untuk memikat perhatian khalayak secara serempak (simultaneous) dan serentak (instantaneous).

\section{Kualitas Layanan Publik}

Kualitas merupakan suatu kondisi dinamis yang berpengaruh dengan produk, jasa, manusia, proses dan lingkungan yang memenuhi atau melebihi harapan (Tjiptono, 2001). Sehingga definisi kualitas pelayanan dapat diartikan sebagai upaya pemenuhan kebutuhan dan keinginan konsumen serta ketepatan penyampaiannya dalam mengimbangi harapan konsumen. Kualitas pelayanan (service quality) dapat diketahui dengan cara membandingkan persepsi para konsumen atas pelayanan yang nyata-nyata mereka terima / peroleh dengan pelayanan yang sesungguhnya mereka harapkan / inginkan terhadap atribut-atribut pelayanan suatu perusahaan. Jika pelayanan yang dirasakan (perceived service) sesuai dengan yang diharapkan, maka kualitas pelayanan dipersepsikan baik dan memuaskan, jika jasa yang diterima melampaui harapan konsumen, maka kualitas pelayanan dipersepsikan sangat baik dan berkualitas.Sebaliknya jika jasa yang diterima lebih rendah daripada yang diharapkan, maka kualitas pelayanan dipersepsikan buruk.

Namun demikian setia jenis pelayanan publik yang diselenggarakan oleh instansi-instansi pemerintahan tentu mempunyai kriteria kualitas tersendiri. $\mathrm{Hal}$ 
ini tentu terkait erat dengan atribut pada masing-masing jenis pelayanan. Ciri-ciri atau atribut-atribut yang ada dalam kual itas tersebut menurut Tjiptono (1996) adalah :

1. Ketepatan waktu pelayanan, yang meliputi waktu tunggu dan waktu proses.

2. A kurasi pelayanan, yang meliputi bebas dari kesalahan-kesalahan.

3. Kesopanan dan keramahan dalam memberikan pelayanan.

4. Kemudahan mendapatkan pelayanan, misalnya banyaknya petugas yang melayani dan banyaknya fasilitas pendukung seperti komputer.

5. Kenyamanan dalam memperoleh pelayanan, berkaitan dengan lokasi, ruang tempat pelayanan, tempat parkir, ketersediaan informasi, dan Iain-lain.

6. A tribut pendukung pelayanan lainnya seperti ruang tunggu ber AC, kebersihan, dan lain-lain.

Dimensi Kualitas Pelayanan

(SERV QUAL) oleh Parasuraman (1998) dibagi menjadi lima dimensi SERV QUAL diantaranya adalah (L upiyoadi, 2001:148):

1. Tangibles (bukti fisik) yaitu kemampuan suatu perusahaan dalam menunjukkan eksistensinya kepada pihak eksternal. Penampilan dan kemampuan sarana dan prasarana fisik perusahaan dan keadaan lingkungan sekitarnya adalah bukti nyata dari pelayanan yang diberikan oleh pemberi jasa. $Y$ ang meliputi fasilitas fisik (gedung, gudang, dan lain sebagainya), perlengkapan dan peralatan yang dipergunakan (teknologi), serta penampilan pegawainya.

2. Reliability (kehandalan) yaitu kemampuan perusahaan untuk memberikan pelayanan sesuai yang dijanjikan secara akurat dan terpercaya. Kinerja harus sesuai dengan harapan pelanggan yang berarti ketepatan waktu, pelayanan yang sama untuk semua pelanggan tanpa kesalahan, sikap yang simpatik, dan dengan akurasi yang tinggi.
3. Responsiveness (ketanggapan) yaitu kemauan untuk membantu dan memberikan pelayanan yang cepat (responsif) dan tepat kepada pelanggan, dengan penyampaian informasi yang jelas.

4. Assurance (jaminan dan kepastian) yaitu pengetahuan, kesopansantunan, dan kemampuan para pegawai perusahaan untuk menumbuhkan rasa percaya para pelanggan kepada perusahaan. Terdiri dari beberapa komponen antara lain komunikasi, kredibilitas, keamanan, kompetensi, dan sopan santun.

5. Emphaty (empati) yaitu memberikan perhatian yang tulus dan brsifat individual atau pribadi yang diberikan kepada para pelanggan dengan berupaya memahami keinginan konsumen. Dimana suatu perusahaan diharapkan memiliki pengertian dan pengetahuan tentang pelanggan, memahami kebutuhan pelanggan secara spesifik, serta memiliki waktu untuk pengoperasian yang nyaman bagi pelanggan.

\section{METODE PENELITIAN}

Penelitian pada hakekatnya bertujuan untuk memberi solusi atas suatu masalah dan mendapat tentang sesuatu yang dianggap benar melalui proses observasi (Ulber, 2010: 9). Penulis memilih jenis penelitian kualitatif ini membahas secara mendalam untuk lebih mengetahui fenomena-fenomena seperti opini, keinginan, perasaan, dan perilaku relasi media tentang strategi dan kegiatan media relation yang dijalankan oleh BKKBN. A nalisis yang penulis gunakaan dalam penelitian ini lebih menekankan pada penggambaran tentang strategi yang digunakan oleh Humas BKKBN Provinsi NTT dalam melaksanakan kegiatan media relation guna meningkatkan kualitas layanan. Analisis digunakan dengan metode kualitatif adalah metode penelitian 
yang digunakan untuk meneliti pada kondisi obyek yang alamiah dengan peneliti sebagai instrumen kunci (Sugiyono, 2010).

Upaya dalam menentukan Informan, peneliti menggunakan Purposive, yaitu teknik pemilihan berdasarkan karakteristik tertentu yang dianggap mempunyai hubungan dengan pelaksanaan strategi dan kegiatan-kegiatan media-media relation yang dijalankan oleh Humas BKK BN. A dapun sumber datanya adalah informan kunci, yaitu orang yang dapat menjaring informasi yang akurat dari berbagai macam sumber terpercaya obyektivitasnya. Penentuan informan kunci berasal dari pejabat struktural pada BKKBN yaitu Kepala Kantor (1 orang) dan KepalaB agianH ubunganM asyarakat (Humas) (1orang), Wartawan yang berperansebagaimitrakerja (2 orang) dan juga masyarakat sebagai pengguna layanan (10 orang).

Teknik pengumpulan data yang dipakai adalah: 1) Wawancara, 2) Observasi, 3) Studi dokumenter. A nalisis data dalam penelitian kualitatif dilakukan pada saat pengumpulan berlangsung, dan setelah pengumpulan data dalam periode tertentu. Miles dan Huberman mengemukakan bahwa aktivitas dalam analisis data kualitatif dilakukan secara interaktif dan terus menerus sampai tuntas, sehingga datanya sudah jenuh. Aktivitas dalam analisis data yaitu data reduction, data display, dan cloncusion drawing/verification. (Sugiyono, 2011).

\section{HASIL DAN PEMBAHASAN}

Penelitian yang dilakukan oleh peneliti pada Bagian Humas BKKBN Provinsi NTT dikhususkan pada kualitas pelayananmelalui media relatios yang meliputi: Keandalan (Reliability), Ketanggapan (Responsiveness), K eyakinan (Assurance), Empati (Empathy) dan B erwujud (Tangibles).
K ualitas Pelayanan melalui strategi media relations di Humas BKKBN Provinsi NTTdalam penelitian ini meliputi:

1. Keandalan (Reliability) yakni Kemampuan dan keandalan layanan Humas BKKBN Provinsi NTT yang berkaitan dengan $M$ edia Relation yaitu ketepatan waktu dalam memberikan informasi dan pelayanan kepada media/wartawan dan masyarakat, pelayanan yang diberikan tanpa ada kesalahan, sikap simpatik dan dengan akurasi yang tinggi serta kemampuan untuk melaksanakan jasa yang dijanjikan dengan cepat dan terpercaya.

2. K etanggapan (Responsiveness) yakniK emampuan Humas BKKBN Provinsi NTT dalam memberikan informasi atau berita kepada media massa di dalam menangani permasalahan atau isu-isu yang timbul di masyarakat serta kemauan untuk membantu pelanggan dan memberikan jasa dengan cepat.

3. Keyakinan (Assurance) yakni pengetahuan dan kesopanan HumasBKKBN Provinsi NTT untuk menimbulkan kepercayaan dan keyakinan, yang merupakan kemampuan Humas dalam menciptakan rasa rasa percaya masyarakat kepada BKK BN NTT, antara lain komunikasi, kredibilitas, keamanan, kompetensi dan sopan santun.

4. Empati (Empathy) yakni sarat untuk peduli, memberi perhatian pribadi bagi pelanggan. Perhatian dan kepedulian serta tanggung jawab Humas HumasBKKBN Provinsi NTT dalam memberikan informasi lewat media atau publikasi dan melakukan eventevent kepada masyarakat yang berkaitan dengan pengetahuan, kebutuhan masyarakat secara spesifik.

5. Berwujud (Tangibles) yakni Humas BKKBN Provinsi NTTmenampilkan fasilitas fisik, peralatan atau teknologi danpenampilan pegawai pada $\mathrm{K}$ antor Badan Koordinasi dan Keluarga Berencana (BKK BN) NTT. 
Dari ke-5 Kualitas pelayanan melalui strategi media relations di Humas BKKBN Provinsi NTT di atas dapat disimpulkan bahwa pelayanan melalui strategi media relations di Humas BKK BN Provinsi NTT sudah berjalan dengan baik karena: a) adanya ketepatan waktu dalam memberikan informasi; b) memberikan informasi atau berita kepada media massa di dalam menangani permasalahan atau isu-isu yang timbul di masyarakat serta kemauan untuk membantu pelanggan dan memberikan jasa dengan cepat; c) menimbulkan kepercayaan dan keyakinan, yang merupakan kemampuan Humas dalam menciptakan rasa rasa percaya masyarakat kepada BKKBN NTT antara lain komunikasi, kredibilitas, keamanan, kompetensi dan sopan santun; d) memberikan informasi lewat media atau publikasi dan melakukan event-event kepada masyarakat yang berkaitan dengan pengetahuan, kebutuhan masyarakat secara spesifik; dan e) menampilkan fasilitas fisik, peralatan atau teknologi dan penampilan pegawai pada Kantor Badan Koordinasi dan Keluarga Berencana (BKKBN) NTT.

Pencapaian Program KKBPK Provinsi Nusa Tenggara Timur Bulan $M$ aret 2016.Dalam penelitian ini yang dimaksud dengan Capaian Program Pelayanan KB dan KS adalah sebagai berikut:

1. Pencapaian Peserta K B B aru (PB)

Pencapaian peserta KB baru sampai dengan $M$ aret 2016 sebanyak 17.476 PB $(13.91 \%$ dari target KKP sebanyak 125.650 PB. Capaian PB tertinggi adalah kabupaten timor tengah selatan yaitu 1.463 peserta K B baru, sedangkan capaian PB terendah adalah kabupaten sabu raijua yaitu 124 peserta K B baru.

Realisasi capaian peserta K B baru (PB) terhadap KKP berdasarkan metode kontrasepsi adalah: IUD 19.61\% (1.200 peserta KB baru dari KKP 6.120 peserta), MOW 19.44\% ( 614 peserta K B baru dari K KP 3.158 peserta), M OP $0.00 \%$ ( 0 peserta KB baru dari KKP
150 peserta), kondom $6.90 \%$ ( 414 peserta KB dari KKP 6.000 peserta), implant $20.78 \%(4,394$ peserta K B baru dari KKP 21.149 peserta), suntikan $14.76 \%$ (9.164 peserta KB baru dari K KP 62.099 peserta), pil $6.27 \%$ (1.690 peserta KB baru dari KKP 26.974 peserta).

2. Pencapaian peserta K B aktif (PA) Pencapaian peserta kb aktif di provinsi NTT sampoai dengan bulan maret adalah $132.8 \%, 415,839$ peserta $k b$ aktif dari kkp 313.140 peserta) dengan rincian : IUD $176.7 \%$ (43.427 peserta kb aktif dari kkp 24.570 peserta), MOW $96.5 \%$ ( 26.271 peserta kb aktif dari kkp 27.220 peserta), M OP $139.7 \%$ ( 2.500 peserta kb aktif dari kkp 1,790 peserta), kondom 217.0\% $\quad(6.705$ peserta kb aktif dari kkp 3.090 peserta), implant $180.0 \%$ ( 89.175 peserta $k b$ aktif dari kkp 49.530 peserta), suntikan $118.2 \%$ ( 203.455 peserta kb aktif dari kkp 172.110 peserta), PIL 127.2\% (44.306 peserta kb aktif dari kkp 34.830 peserta).

Capaian peserta PA terhadap PUS data bulan maret yaitu 59.9\% ( 415.839 peserta kb aktif dari total PUS 693.896 peserta).

3. Cakupan kegiatan PIK R/M , bina ketahanan keluarga dan UPPK S

a. jumlah PIK remaja/mahasiswa sampai dengan bulan maret $2016 \mathrm{di}$ provinsi NTT 684 kelompok yang terdiri dari :

1. Tahap tumbuh: 557 kelompok

2. Tahap tegak : :91 kelompok

3. Tahap tegar : : 36 kelompom

b. jumlah kelompok bina ketahanan keluarga bulan maret 2016 yaitu :
1. BKB : 1657 kelompok
2. $B K R$ : 790 kelompok
3. $B K L$ : 999 kelompok

c. jumlah kelompok UPPK S bulan maret yaitu : 734 kelompok.

Dari data di atas dapat disimpulkan bahwa dari Pencapaian 
Program Pelayanan KB dan KS sampai dengan Bulan maret 2016 sudah berjalan dengan baik dan sesuai dengan teori pelayanan melalui media relations yaitu keseluruhan kegiatan yang meliputi Keandalan (Reliability), K etanggapan (Responsiveness), K eyakinan (Assurance), Empati (Empathy) dan Berwujud (Tangibles).Hal ini akanmenjadi acuan untuk lebih meningkatkan kualitas pelayanan BKKBN Provinsi NTT ke depannya.

\section{KESIMPULAN}

K ualitas Pelayanan melalui strategi media relations di Humas BKKBN Provinsi NTT adalah sebagai berikut:

a. Keandalan (Reliability) yakni Kemampuan dan keandalan layanan Humas BKKBN Provinsi NTT yang berkaitan dengan M edia R elation yaitu ketepatan waktu dalam memberikan informasi dan pelayanan kepada media/wartawan dan masyarakat, pelayanan yang diberikan tanpa ada kesalahan, sikap simpatik dan dengan akurasi yang tinggi serta kemampuan untuk melaksanakan jasa yang dijanjikan dengan cepat dan terpercaya.

b. Ketanggapan (Responsiveness) yakniK emampuan Humas BKKBN Provinsi NTT dalam memberikan informasi atau berita kepada media massa di dalam menangani permasalahan atau isu-isu yang timbul di masyarakat serta kemauan untuk membantu pelanggan dan memberikan jasa dengan cepat.

c. Keyakinan (Assurance) yakni pengetahuan dan kesopanan HumasBKKBN Provinsi NTT untuk menimbulkan kepercayaan dan keyakinan, yang merupakan kemampuan Humas dalam menciptakan rasa rasa percaya masyarakat kepada BKKBN NTT, antara lain komunikasi, kredibilitas, keamanan, kompetensi dan sopan santun. d. Empati (Empathy) yakni sarat untuk peduli, memberi perhatian pribadi bagi pelanggan. Perhatian dan kepedulian serta tanggung jawab Humas HumasBKKBN Provinsi NTT dalam memberikan informasi lewat media atau publikasi dan melakukan eventevent kepada masyarakat yang berkaitan dengan pengetahuan, kebutuhan masyarakat secara spesifik.

e. Berwujud (Tangibles) yakni Humas BKKBN Provinsi NTT menampilkan fasilitas fisik, peralatan atau teknologi danpenampilan pegawai pada $\mathrm{K}$ antor Badan Koordinasi dan Keluarga Berencana (BK K B N) NTT.

Dari ke-5 Kualitas pelayanan melalui strategi media relations di Humas BKKBN Provinsi NTT di atas dapat disimpulkan bahwa pelayanan melalui strategi media relations di Humas BKK BN Provinsi NTT sudah berjalan dengan baik karena: a) adanya ketepatan waktu dalam memberikan informasi; b) memberikan informasi atau berita kepada media massa di dalam menangani permasalahan atau isu-isu yang timbul di masyarakat serta kemauan untuk membantu pelanggan dan memberikan jasa dengan cepat; c) menimbulkan kepercayaan dan keyakinan, yang merupakan kemampuan Humas dalam menciptakan rasa rasa percaya masyarakat kepada BKKBN NTT antara lain komunikasi, kredibilitas, keamanan, kompetensi dan sopan santun; d) memberikan informasi lewat media atau publikasi dan melakukan event-event kepada masyarakat yang berkaitan dengan pengetahuan, kebutuhan masyarakat secara spesifik; dan e) menampilkan fasilitas fisik, peralatan atau teknologi dan penampilan pegawai pada Kantor Badan Koordinasi dan Keluarga Berencana (BKK BN) NTT.

Dari data yang ada dapat disimpulkan bahwa dari Pencapaian Program Pelayanan KB dan KS sampai dengan Bulan maret 2016 sudah berjalan dengan baik dan sesuai dengan teori pelayanan melalui media relations yaitu 
keseluruhan kegiatan yang meliputi Keandalan (Reliability), K etanggapan (Responsiveness), K eyakinan (Assurance), Empati (Empathy) dan Berwujud (Tangibles). Hal ini akan menjadi acuan untuk lebih meningkatkan kualitas pelayanan BKKBN Provinsi NTT ke depannya.

\section{DAFTAR PUSTAKA}

A rdianto, Elvinaro. 2011. Handbook of Public Relation. Simbiosa Rekatama M edia. B andung

Cutlip, Scott M.,dkk.. 2006. Effective Public Relations, Jakarta: Prenada Media Group

Iriantara, Y osal. 2005. Media Relations. Ba ndung : Simbiosa Rekatma M edia.

Kotler, Philip. 2002. Manajemen Pemasaran di Indonesia: Analisis, Perencanaan, Implementasi dan Pengendalian. Salemba Empat. J akarta.

Lesly, Philip. 1991. Lesly's Handbook of Public Relations and Communications. Chicago, Illinois: Probus Publishing Company.

Ruslan, Rosady.2006. Manajemen Public relations dan Media Komunikasi, Konsepsi dan Aplikasi. Jakarta. Raja Grafindo Persada.

Tjiptono, Fandy. 2001. StrategiPemasaran. EdisiPertama. A ndiO fset.Y ogyakarta.

Toth, PP. 2009. A theroschlerosis: The Underlying Disease. Journal Fam Pract. 58, (11) 1-17. 